\title{
Corporate Social Responsibility As A Tool To Ensure The Well-Being Of Monotowns In Russia
}

\author{
Asya Sechina \\ Institute of social and humanitarian technologies \\ Tomsk Polytechnic University \\ Tomsk, Russia \\ frog555@yandex.ru
}

\author{
Anna Fedenkova \\ Institute of social and humanitarian technologies \\ Tomsk Polytechnic University \\ Tomsk, Russia
}

\author{
Natalia Pokrovskaya \\ Institute of social and humanitarian technologies \\ Saint-Petersburg State University \\ St.Peterburg, Russia
}

German Kurmel

Institute of physics of high technologies

Tomsk Polytechnic University

Tomsk, Russia

\begin{abstract}
The article provides an analysis of the historical development and the formation of monotowns, examines the signs of the specificity of monotowns, the classification of different types of development of monotowns. There isthe concept of corporate social responsibility. It examines the concept of corporate social responsibility of business, its functions, structure and its influence on the development of economy, society and the local community. There is the descriptionof the benefits of running a socially responsible business and the use of the concept of corporate social responsibility. There is the classification of examples of investments for implementation of programs of corporate social responsibility. It outlines a hypothesis of the mechanisms on the basis of corporate social responsibility and concepts of ethical business practice to ensure social and economic sustainability of monotowns.
\end{abstract} ethics

Keywords-monotown; corporate social responsibility; business

In the modern system of the Russian economy monotowns are a special phenomenon. The majority of Russian monotowns created in the planned economy, and most monotowns became a concentration of complex economic and social problems in transition to market economy. The global challenge is to develop a number of mechanisms for the development of this type of cities, or their reorganization. It is clear that the main factor here is not even a company, and people who due to the nature of monotowns are vulnerable on a number of issues. But the problem of monotowns should not be only a problem of regional and Federal government, it is also important the participation of businesses in solving the problems of monotowns.

In the middle of the XIX century in Russia about nine percent of the population lived in cities. But less than a hundred years Russia from the country where the majority of the population lived in rural areas has become a country of cities and citizens. According to the statistics today, more than $75 \%$ of the population lives in cities. Modern Russian city, which occupies about half a percent of the country, concentrated in a large proportion of the capital and are centers of economic development. But besides the development of a number of spheres of life, development of cities led to urbanization problems. The most acute of them: unemployment, criminality, reduced life expectancy, increased morbidity, and environmental problems.

Monoprofile towns, or as they are called - monotowns, which occupies a special place in the community and the economy of the country, are named as projection of urban issues and problems in socio-economic sphere of the country as a whole. Monotowns are traditional for the Russian economy.

It is possible to identify their main stages of formation:

1. The reign of Peter I. the First stage of development of industrialization of the country demanded the creation of new industries. The centers of these productions were cities. Due to the fact that at that time there were no specialized professionals, these cities were attributed to the peasants, often from neighboring villages;

2. The second stage is associated with the development of light industry in Russia; create manufactory, which also used the labor of the peasants. In the same period observed the formation of settlements around mines;

3. In Soviet times the number of monotowns has increased dramatically. Monotowns developed, created entire complexes one profile companies. Also in time of war towns are formed by the evacuated enterprises;

4. After the war there is the dispersal of the productive forces from major cities and attracting labor from the local population. Also this period is characterized by the tendency to the development of the construction of the new facilities, which later became the city-forming.

Thus, the existence in the Russian economy of the monoprofile towns is natural, therefore, to assess unambiguously with good or bad sides is not possible.

Currently a clear definition of what the monotown does not exist. Most studies cite as a definition a brief description of the specifics of monoprofile towns. The monotowns is regarded as a town with city-forming enterprise, which employs most of the population of the town. In this regard, it is the center of existence of monotown.

According to the researchers town can be called monotown if we can highlight the following features: 
- Availability of one or more enterprises, which can be attributed to one industry, serving a narrow segment of the market;

- Other companies operating in the city provide only the internal needs of the population of the city;

- The dependence of city budget from the activity of one or more enterprises;

- The low diversification of fields of activity of the population;

- Remoteness from major cities.

It is also impossible to say that all towns are disadvantaged. It is possible to distinguish three types of monotowns:

1. Relatively successful city operating in the sphere of military-industrial complex, and maintaining permanent financial support from the state. This group also includes enterprises in oil and gas industry. The city sustained even during the crisis;

2. Company towns in which town-forming enterprise is not very promising, but in the future as a result of a change of ownership and restructuring of the fields of activity can be safely functioning;

3. Unpromising monotowns with the main enterprise. Such towns are the most in the country.

Despite the fact that not all monotowns are economically depressed, yet they will be united by one tendency: the restriction of economic and social opportunities for residents of these towns.

Ensuring the sustainability of monotowns development is based on creating a mechanism of changing the situation in monotowns, which would be adequate to the market system and therefore providing the possibility of self-development such settlements and their adaptation to changes in the external environment, without recourse to assistance and resources of the state. And solve problems of monotowns should not be only the problem of the state, enterprises operating in the monotown should also participate in solving these problems. Mechanism for solving a number of problems of monotowns may be corporate social responsibility (CSR). In monotowns there is a close relationship between the state, communities and enterprise, on the basis of which there can be a successful mechanism of CSR.

Corporate social responsibility is a philosophy of conduct and a concept of building up the company's efforts to meet the expectations of stakeholders for sustainable development. Moreover, CSR cannot be regarded as the ratio of the company and society as a whole. The modern organization is a complex part of the environment, including a large number of components, on which depends the existence of the organization. These components include suppliers, competitors, the media, unions and associations, as well as employees and shareholders. This multi-layered social environment has a great influence on the achievement of the goals of the organization, so the organization has to balance purely economic objectives with the economic and social interests of these elements of the environment. Organizations have a responsibility to the society in which they operate, so they should direct some of their resources and efforts to social needs, to sacrifice for the benefit of improving society.

It is important to note that the practice of using CSR programs is not new for Russia. Large enterprises in the Soviet period supported the social sphere and infrastructure of their region. For example, at the time workers received free vouchers from the company, had a long paid vacation. But the program CSR was not considered as part of the strategy of the organization, but also as a tool to maintain the sustainability of the enterprise. Currently Russia is integrating into the world community and CSR activities are gradually approaching global standards.

A socially responsible strategy can be extremely useful for the organization. Thus the traditional benefits of running a socially responsible business:

- A more attractive image of the organization in society;

- Increases the credibility of the organization;

- Increasing turnover, number of customers etc., this is due to the improvement of the attitude of the organization;

- There is an opportunity to get more profitable orders;

- Increased credibility, the organization may conduct more active and effective policy in the company, expanding its activities, in particular markets;

- There is an opportunity to reduce local taxes, etc.

An effective policy of social responsibility should be based on certain principles that can guide the organization: 1) organization must be primarily directed at the person; 2) assistance should be aimed at meeting basic physiological needs in food, housing, recreation, clean water, security, etc.

For the successful functioning of the organization should be able to be distracted by problems arising in the social environment to make the environment favorable for them. The costs of social responsibility are justified by the factor of the development of different segments of the society, and improving public attitudes to the organization. This should lead to increased consumer loyalty to the product manufacturers. The organization should analyze their own actions and their environment and to choose such programs of social responsibility that will help the environment to the greatest extent.

With regard to monotowns, the concept of CSR should also be based primarily on the needs of the population of monotowns. As such, the problem of monotowns is largely a social, not economic. As already mentioned, the population of monotowns characterize by low mobility, both labor and the inability to move to other larger cities. But the key issue in the modernization and innovative development is the formation of socio-cultural institutions.

Development of CSR tools should correlate with the real problems of society, with social order. Only in this case, social investment will be effective. The existence of a social order allows us to speak about the effectiveness of social policies, as changing the real problems that gave birth to it, and effectively analyze the percentage of target use of funds and organizational expenses. In some regions such experience practiced, for example, hearings, fairs of ideas, etc. Such 
experience needs to be expanded and develop the techniques and the mechanism of acceptance of social order and analysis of the needs of society as well as in the development of methods for the implementation of social programs.Development of CSR tools should correlate with the real problems of society, with social order. Only in this case, social investment will be effective. The existence of a social order allows us to speak about the effectiveness of social policies, as changing the real problems that gave birth to it, and effectively analyze the percentage of target use of funds and organizational expenses. In some regions such experience practiced, for example, hearings, fairs of ideas, etc. Such experience needs to be expanded and develop the techniques and the mechanism of acceptance of social order and analysis of the needs of society as well as in the development of methods for the implementation of social programs.

This point is important in relation to the restructuring and development of monotowns. It is important to raise awareness and creating an active social position of the society, the readiness of the society to innovative development. All this often requires considerable personal work. The tool implementation may be complex in information and communication technologies on the formation of attitudes on the creation of a new quality of life. In this sense, social investment is an infusion that will stimulate the development of the region. It is important to remember that it is not just about propaganda, namely the formation of a mutually responsible social partnership. Also the most important tools will be: to attract attention of the population to the most effective practices of social investment and social partnership; establishment of business relations with different social groups of market and non-market environment; the creation of conditions constructive public dialogue, the consolidation of society in a constructive manner. The generalization of such experience gives a methodical procedure, a specific technology, identifying possible participants of social dialogue and partnership, creation on this basis of operations and procedures. Ultimately, it will be a movement towards the formation of civil society.

\section{REFERENCES}

[1] P.R.P. Coelho, J.E. McClure, J.A. Spry, "The social responsibility of corporate management: a classical critique", American journal of business. Cleveland: Emerald publishing group, 2003, 18, 1, pp. 15-24.

[2] A.B. Carroll, "The pyramid of corporate social responsibility: towards the moral management of organizational stakeholders", Business horizon, July-August, Elsevier, 1991, pp.39-48.

[3] N.V. Cherepanova, "Communication Technologies in Contemporary Corporate Social Responsibility Management" [Electronic resource] / N. V. Cherepanova, L. R. Tukhvatulina, A. Eremina // Procedia - Social and Behavioral Sciences, 2015, Vol. 166: Proceedings of The International Conference on Research Paradigms Transformation in Social Sciences 2014 (RPTSS-2014), 16-18 October 2014, Tomsk, Russia, pp. 583-588.

[4] I.S. Antonova, O.A. Negodina, D.D. Vavilov "Russian company town: creteria and diversification results", 26th International Business Information Management Association Conference: Proceedings IBIMA Madrid, November 11-12, 2015. - Madrid: IBIMA, 2015, pp. 2181-2187

[5] N.O. Chistyakova, A.S. Fedenkova, N.V. Shabaldina, Y.V. Abushakhmanova, "Innovation Networks as Elements of Regional Innovation System: State-of-Art Review", The 26th International Business Information Management Association Conference: Proceedings IBIMA, Madrid, November 11-12, 2015. - Мадрид: IBIMA, 2015, pp. 1653-1662

[6] K.A.Bannova, I.N.Dolgih, A.B.Zhdanova, N.V. Pokrovskaya, "Developing The Competitive Advantage Of Companies And Regions By The Creation Of Consolidated Groups Of Taxpayers", IBIMA, 2015, pp. 834-841. 